\title{
DIGNITY
}

\section{Dignity: A Journal of Analysis of Exploitation and Violence}

Volume 6

\section{Introduction: Dignity's Special Issue on the Chab Dai Coalition's Butterfly Longitudinal Research Project}

Leslie M. Tutty

University of Calgary, tutty@ucalgary.ca

Follow this and additional works at: https://digitalcommons.uri.edu/dignity

Part of the Asian Studies Commons, Civic and Community Engagement Commons, Community-Based Research Commons, Development Studies Commons, Domestic and Intimate Partner Violence Commons, Family, Life Course, and Society Commons, Inequality and Stratification Commons, Other Social and Behavioral Sciences Commons, Politics and Social Change Commons, and the Social Work Commons

\section{Recommended Citation}

Tutty, Leslie M. (2021) "Introduction: Dignity's Special Issue on the Chab Dai Coalition's Butterfly Longitudinal Research Project," Dignity: A Journal of Analysis of Exploitation and Violence: Vol. 6: Iss. 4, Article 1. https://doi.org/10.23860/dignity.2021.06.04.01

This Article is brought to you for free and open access by DigitalCommons@URI. It has been accepted for inclusion in Dignity: A Journal of Analysis of Exploitation and Violence by an authorized editor of DigitalCommons@URI. For more information, please contact digitalcommons-group@uri.edu. 


\title{
Introduction: Dignity's Special Issue on the Chab Dai Coalition's Butterfly Longitudinal Research Project
}

\author{
Keywords \\ Cambodia, Butterfly Project, Chab Dai Coalition, human trafficking, sexual exploitation, longitudinal \\ research, victims, survivors, reintegration \\ Creative Commons License \\ (c) (i) $(\Theta)$
}

This work is licensed under a Creative Commons Attribution-Noncommercial-No Derivative Works 4.0 License.

\section{Acknowledgements}

The author and editor thanks the anonymous peer reviewers who provided helpful comments and suggestions. 


\title{
DIGNITY AJOURAL OF AMALYIIS
}

Volume 6, Issue 4, Article 1, 2021

https://doi.org/10.23860/dignity.2021.06.04.01

\section{INTRODUCTION: \\ DIGNITY'S SPECIAL ISSUE ON THE CHAB DAI \\ COALITION'S BUTTERFLY LONGITUDINAL RESEARCH PROJECT}

\author{
Leslie M. Tutty \\ Special Issue Editor, University of Calgary, Canada \\ (D)0000-0003-3000-7601
}

\section{KEYWORDS}

Cambodia, Butterfly Project, Chab Dai Coalition, human trafficking, sexual exploitation, longitudinal research, victims, survivors, reintegration

$D$ IGNITY: A JOURNAL OF ANALYSIS OF EXPLOITATION AND VIOLENCE is pleased to partner with the Chab Dai Coalition's Butterfly Longitudinal Research Project to present this special edition on the major findings of the project on the sexual exploitation of individuals in Cambodia. This collection of seven peer-reviewed articles represents a significant body of research, following the lives of 128 Cambodian child and adult survivors of human trafficking, exploitation and abuse over a ten-year period. The articles touch on numerous aspects of the lives of these individuals including the social determinants of health, justice system responses, stigma and the difficulties re-integrating back into their communities. One article is specific to the experiences of the study's male cohort.

While some research from the Butterfly Project has been published, this special edition presents the most current results from the completed project. The body of knowledge created could have important implications for both Cambodia and other countries that deal with significant trafficking/sexual exploitation, as well as for the NGOs that support survivors in after-care shelters and as the survivors re-integrate into their home communities.

It is rare to have the capacity to conduct such a comprehensive body of research on sexual exploitation in any one country and the lack of longitudinal studies on sex trafficked survivors has been noted (Knight et al., 2021). Funding for longitudinal studies on any topic is difficult to obtain. Following the same individuals over time is challenging; problems relocating participants across study waves are common.

This introduction to the special edition presents a brief overview of human sex trafficking worldwide, describing core concepts, policies and interventions to provide context for the studies presented in the special edition. It, then, narrows to global research on sex trafficking, concluding with studies from Southeast Asia and Cambodia. Finally, the articles are briefly described. 


\section{HUMAN SEX TRAFFICKING}

Human trafficking is a broad term that incorporates sex trafficking, labour trafficking, slavery and organ trafficking (International Labour Organization, 2017). The considerable body of research on this topic is diverse: some focus broadly on human trafficking, while others narrow to a more specific focus on sex trafficking, labour trafficking, or the sexual exploitation of children. There is certainly overlap in the experiences of those who are trafficked such that many are forced into multiple forms, however, each group also has distinct characteristics that make it important to carefully pay attention to the main focus of each publication.

The forced sexual exploitation of adults and commercial sexual exploitation of children is a problem that has existed over the ages but has finally garnered societal attention over the last twenty years, which Russell (2018) links to the proclamation of The Protocol to Prevent, Suppress, and Punish Trafficking in Persons Especially Women and Children (the Trafficking Protocol) (United Nations General Assembly, 2000), otherwise known as the Palermo Protocol. This was the first international effort to address human trafficking (Bryant \& Landman, 2020). It has been updated and tailored for different countries, but the principles remain similar.

Sex trafficking is defined as "the recruitment, harboring, transportation, provision, or obtaining of a person for the purpose of a commercial sex act ... in which a commercial sex act is induced by force, fraud, or coercion, or in which the person induced to perform such an act has not attained 18 years of age" (United Nations General Assembly, 2000). Some prefer terms such as "sexual exploitation" over "sex trafficking" however, debates about definitions and their implications are common and certainly affect how the constructs are measured (Benoit et al., 2019; Nawyn et al., 2013).

While it is difficult to estimate how many individuals are currently sex-trafficked, a recent report by the International Labour organization (2017) proposed that 4.8 million people globally were sexually exploited in the year 2016 alone. These were primarily women and girls (99\%), although the sexual exploitation of boys and men may well be under-reported. The majority (70\%) of forced sexual exploitation victims were from Asia and the Pacific region (Internatonal Labour Organization, 2017).

The physical and sexual violence entailed in being a victim of sexual exploitation results in significantly negative health and mental health consequences that have been well-documented (Kiss et al., 2015a; Oram et al., 2012) and includes PTSD at levels greater than having been sexually abused as a child but not trafficked (Cole et al., 2016). Many of these mental health issues continue into adulthood, primarily affecting intimate relationships and intimacy, resulting in partner violence for many (Puente-Martínez et al., 2019; Thaller \& Cimino, 2017). In contrast, some researchers have focused on the resilience of individuals who have been trafficked, highlighting strengths such as positive interpersonal relationships (Knight et al., 2021).

Responses to address sexual exploitation include policies (Hounmenou \& O'Grady, 2019) and programs (Dell et al., 2019; Kaufman \& Crawford, 2011; Limoncelli, 2016; Macy \& Johns, 2011; McCarthy, 2018; Muraya \& Fry, 2016), although more research on interventions to address sex trafficking is sorely needed (Knight et al., 2021). Difficulty accessing health resources is a common problem (Price et al., 2019). Awareness campaigns to prevent sex-trafficking are rare, but interesting (Harper et al., 2018; O’Brien, 2016). 


\section{INTERNATIONAL RESEARCH ON SEX TRAFFICKING}

There is a considerable body of global research with respect to the forced sexual exploitation of adults and the commercial sexual exploitation of children. While this introduction cannot provide an in-depth overview of research world-wide, examples of publications in the developed world include research in the US (Hampton \& Lieggi, 2020), Canada (Baird et al., 2020; Sethi, 2007), the United Kingdom (Cockbain \& Wortley, 2015), Australia (Davy, 2017) and Europe, including Russia and Poland (Benavente et al., 2021; Hughes, 2014).

Research has been conducted in developing countries and continents such as in Latin and South America (Downe, 2007; Studnicka, 2010; Zhang et al., 2012). Research in Africa includes Lasater et al.'s research in Togo (2019), Adjei and Saewyc's research in sub-Saharan countries (2017) and Azage et al.'s work in Ethiopia (2014).

Given the previously mentioned high prevalence of sex trafficking in Asia and the Pacific regions, the heavy research focus in these areas is understandable. In South Asia, research has been conducted in India (da Silva \& Sathiyaseelan, 2019; Parks et al., 2018), in Maritime South East Asia and in the Philippines (Williams et al., 2010; Davis \& Miles, 2020).

Numerous researchers have examined sex trafficking in Southeast Asia, studying the phenomenon in Malaysia (Mahalingam \& Sidhu, 2020), the Mekong region, which includes Thailand, Laos, Cambodia Vietnam, Myanmar and the Chinese province of Yunnan (Kiss, et al., 2015b; Molland, 2018; Tsai \& Dichter, 2019), the country of Thailand specifically (Davis et al., 2017; Davis et al., 2019), Nepal (Basnyat, 2020; Dahal et al., 2015; Kaufman \& Crawford, 2011; Ong et al., 2019) and Vietnam (Le, 2017; Davis \& Miles, 2018; Glotfelty \& Miles, 2018)

Moving to the site of the current special edition, studies centred in Cambodia or a few that included Cambodia in addition to other South East Asian countries examined individuals working in industries that often overlap or hide sexual trafficking such as female masseuses (Miles et al., 2020), male masseuses (Blanch \& Miles, 2012), and hostesses in karaoke TV venues (Miles \& Alsiyao, 2019). Others examined whether sexually trafficked women could reintegrate into churches (Hester et al., 2020), the legal regulation of women's bodies (Bradley \& Szablewska, 2016), and access to health and mental health services by survivors (Aberdein \& Zimmerman, 2015); Davis \& Miles, 2018).

Several researchers have focused on Cambodian youth (Davis et al., 2021; Gray et al., 2012; Kiss, et al., 2015b; Nodzenski et al., 2020). Blackburn et al. (2010) and Davy (2014) interviewed experts about their perspectives of how best to respond to children who are sex trafficked in Thailand and Cambodia.

Researchers from the Chab Dai collective have previously published articles with respect to the Butterfly Project. Cordisco Tsai, et al. (2020a) examined perspectives of 79 individuals as they moved from the shelter back into the community. Cordisco Tsai et al. (2020b) and Cordisco Tsai et al. (2020c) followed males over time as they transitioned back into the community. Cordisco Tsai et al. (2020d) examined the entire cohort of 128 individual's relationships with aftercare shelter staff over time, while Cordisco Tsai et al. (2021) focused on ten women's relationships with shelter personnel.

In summary, despite the plethora of international research conducted with respect to sexual exploitation and trafficking, it is rare for studies to concentrate on any one country or to attempt longitudinal research examining how individuals fare over 
time, after having been provided services to assist their re-integration. The research articles presented in this special edition do just that.

\section{DIGNITY'S SPECIAL EDITION}

This collection of seven peer-reviewed articles presents the most up-to-date research with respect to a range of topics that highlights the breadth of the ten-year project Chab Dai Coalition's Butterfly Longitudinal Research Project.

To set the stage for the subsequent articles in the special edition, Glenn Miles, James Havey, Eliza Piano, Vanntheary Lim, Nhanh Chantha, Sreang Phaly and Sopheara Ou introduce the research project in their article, "I don't want the next generation of children to be in pain like me": The methodology and key findings of the ten-year Chab Dai ten-year Butterfly Longitudinal Research Project on sex trafficking survivors in Cambodia.' This article describes the genesis of the Butterfly Project, the research methodologies used over time and chronicles ten major project findings.

The relative neglect of boys in research on sex trafficking has been noted (i. e. Adjei \& Saewyc, 2017). Jarrett Davis, James Havey, Glenn Miles, Vanntheary Lim, and Nhanh Chantha present mixed-method research with respect to the experiences of boys/young men in shelter care and re-integration in "Going it alone": Following the male cohort of participants in the Chab Dai Butterfly Longitudinal Research Project.'

That stigma impacts sex workers globally both when they are working and after they reintegrate is well-accepted (Benoit et al., 2018). Todd Morrison, Vanntheary Lim, Nhanh Chantha, James Havey and Glenn Miles present qualitative research examining how stigma and discrimination affect a cohort of 56 Butterfly Project participants in their paper, "You have to be strong and struggle": Stigmas as determinants of inequality for female survivors of human sexual trafficking in Cambodia.'

"Filial piety" is a concept that is common is Eastern cultures. It refers to family obligations, especially concerning finances. Julia Smith-Brake, Vanntheary Lim and Nhanh Chantha examine filial piety and financial anxiety/security in a cohort of 90 Butterfly Project participants. The article is titled: "'Why am I the only one responsible for the whole family?": Expressions of economic filial piety and financial anxiety among female survivors of sex trafficking.'

James Havey, Glenn Miles, Tehillah Eskelund, Lim Vanntheary, Nhanh Chantha, and Hanni Stoklosa next present a quantitative research paper with respect to the social health determinants of Butterfly Project participants, "When they see someone who is poorer than them, they step on that person": The social determinants of health among survivors of sex trafficking in the Chab Dai Butterfly Longitudinal Research Project."

Next, James Havey, John Morrissey, Vanntheary Lim, and Nhanh Chantha offer a qualitative paper examining at the experiences of the Butterfly Project cohort in the legal system in Cambodia. Entitled: "I want justice from people who did bad things towards children'”: Experiences and perceptions of justice for sex trafficking survivors from the Butterfly Longitudinal Research Project." The article chronicles the experiences of a small cohort of study respondents who went to court either as complainants or as witnesses.

Finally, given that few longitudinal studies have followed sex trafficking survivors after they sought assistance to leave (Russell, 2018), it should be no surprise that we know almost nothing about the risks of re-exploitation. The final article, written by Tania DoCarmo, Vanntheary Lim, and Nhanh Chantha, addresses what happens to 
female survivors after shelter aftercare intervention. It is entitled: “I don't know where else to go:' Pathways to re-exploitation after female trafficking survivors in Cambodia return home."

To summarize, these articles provide both broad and in-depth information with respect to individuals who have been trafficked in Cambodia, portraying their struggles and successes. Each article includes direct quotes that frame the survivors' journeys with poignant and often-evocative narratives. In our view, this special edition offers a unique and comprehensive perspective of their lives and the efforts of those who seek to assist them.

\section{ACKNOWLEDGMENTS}

The author and editor thanks the anonymous peer reviewers who provided helpful comments and suggestions.

\section{AUTHOR BIOGRAPHY}

Leslie Tutty, Ph.D., is a professor emerita with the Faculty of Social Work, University of Calgary, Canada, where she taught clinical social work and research. Her research has focused on intimate partner violence, child abuse and sexual exploitation, evaluating clinical services such as violence against women shelters and support groups for abused women, groups for children exposed to intimate partner violence and groups for men who abuse partners.

\section{RECOMMENDED CITATION}

Tutty, Leslie M. (2021). Introduction: Dignity's special issue on the Chab Dai Coalition's Butterfly Longitudinal Research project. Dignity: A Journal of Analysis of Exploitation and Violence. Vol. 6, Issue 4, Article 1. https://doi.org/10.23860/dignity.2021.06.04.01 Available at http://digitalcommons.uri.edu/dignity/vol6/iss4/1.

\section{REFERENCES}

Aberdein, C., \& Zimmerman, C. (2015). Access to mental health and psychosocial services in Cambodia by survivors of trafficking and exploitation: A qualitative study. International Journal of Mental Health Systems, 9, 16. https://doi.org/10.1186/s13033-015-0008-8

Adjei, J. K., \& Saewyc, E. M. (2017). Boys are not exempt: Sexual exploitation of adolescents in sub-Saharan Africa. Child Abuse \& Neglect, 65(1), 14-23. https://doi.org/10.1016/i.chiabu.2017.01.001

Azage, M., Abeje, G., \& Mekonnen, A. (2014). Sex trafficking awareness and associated factors among youth females in Bahir Dar town North-West Ethiopia: A community based study. BMC Women's Health, 14(1). http://www.biomedcentral.com/1472$\underline{6874 / 14 / 85}$

Baird, K., McDonald, K. P., \& Connolly, J. (2020). Sex trafficking of women and girls in a Southern Ontario region: Police file review exploring victim characteristics, trafficking experiences, and the intersection with child welfare. Canadian Journal of Behavioural Science, 52(1), 8-17. https://doi.org/10.1037/cbs0000151

Basnyat, I. (2020). Stigma, agency, and motherhood: Exploring the performativity of dual mother-female sex workers identities in Kathmandu, Nepal. Journal of International and Intercultural Communication, 13(2), 98-114. https://doi.org/10.1080/17513057.2020.1735486

Benavente, B., D'raz-Faes, D. A., Ballester, L., \& Pereda, N. (2021). Commercial sexual exploitation of children and adolescents in Europe: A systematic review. Trauma, Violence, \& Abuse. https://doi.org/10.1177/1524838021999378 
Benoit, C., Jansson, S. M., Smith, M., \& Flagg, J. (2018). Prostitution stigma and its effect on the working conditions, personal lives, and health of sex workers. The Journal of Sex Research, 55(4/5), 457-471. https://doi.org/10.1080/00224499.2017.1393652

Benoit, C., Smith, M., Jansson, M., Healey, P., \& Magnuson, D. (2019). Unlinking prostitution and sex trafficking: Response to commentaries. Archives of Sexual Behavior, 48(7), 1973-1980. https://doi.org/10.1007/s10508-019-1461-2

Blackburn, A. G., Taylor, R. W., \& Davis, J. E. (2010). Understanding the complexities of human trafficking and child sexual exploitation: The case of Southeast Asia. Women \& Criminal Justice, 20(1-2), 105-126. https://doi.org/10.1080/08974451003641099

Blanch, H., \& Miles, G. (2012). An initial exploration of young males in the male-to-male massage industry in Phnom Penh, Cambodia. Social Work and Christianity, 39(4).

Bradley, C., \& Szablewska, N. (2016). Anti-trafficking (ILL-)efforts: The legal regulation of women's bodies and relationships in Cambodia. Social \& Legal Studies, 25(4), 461488. https://doi.org/10.1177/0964663915614885

Bryant, K. \& Landman, T. (2020). Combatting human trafficking since Palermo: What do we know about what works? Journal of Human Trafficking, 6(2), 119-140. https://doi.org/10.1080/23322705.2020.1690097

Cockbain, E., \& Wortley, R. (2015). Everyday atrocities: Does internal (domestic) sex trafficking of British children satisfy the expectations of opportunity theories of crime? Crime Science, 4(1). https://doi.org/10.1186/s40163-015-0047-0

Cole, J., Sprang, G., Lee, R., \& Cohen, J. (2016). The trauma of commercial sexual exploitation of youth: A comparison of CSE victims to sexual abuse victims in a clinical sample. Journal of Interpersonal Violence, 31(1), 122-146. https://doi.org/10.1177/0886260514555133

Cordisco Tsai, L., Lim, V., \& Nhanh, C. (2020a). "I feel like we are people who have never known each other before": The experiences of survivors of human trafficking and sexual exploitation transitioning from shelters to life in the community. Qualitative Social Research, 21(1). https://doi.org/10.17169/fqs-21.1.3259

Cordisco Tsai, L., Lim, V., \& Nhanh, C. (2020b). Experiences of trafficked and sexually exploited boys transitioning from shelter programmes into the community: Findings from a longitudinal study. Children \& Society, 34(5), 392-407. https://doi.org/10.1111/chso.12376

Cordisco Tsai, L., Lim, V., \& Nhanh, C. (2020c). Perspectives of boys on their experiences in human trafficking shelter programming in Cambodia. Journal of Human Behavior in the Social Environment. https://doi.org/10.1080/10911359.2020.1845902

Cordisco Tsai, L., Lim, V., \& Nhanh, C. (2020d). Perspectives of survivors of human trafficking and sexual exploitation on their relationships with shelter staff: Findings from a longitudinal study in Cambodia. British Journal of Social Work, 50, 176-194. https://doi.org/10.1093/bjsw/bcz128

Cordisco Tsai, L., Lim, V., Nhanh, C., \& Namy, S. (2021). "They did not pay attention or want to listen when we spoke": Women's experiences in a trafficking-specific shelter in Cambodia. Affilia: Journal of Women and Social Work. https://doi.org/10.1177/0886109920984839

da Silva, I. M., \& Sathiyaseelan, A. (2019). Emotional needs of women post-rescue from sex trafficking in India. Cogent Psychology, 6(1). https://doi.org/10.1080/23311908.2019.1631584

Dahal, P., Joshi, S. K., \& Swahnberg, K. (2015). 'We are looked down upon and rejected socially': A qualitative study on the experiences of trafficking survivors in Nepal. Global Health Action, 8(1). https://doi.org/10.3402/gha.v8.29267 
Davis, J. D., \& Miles, G. M. (2018). “They chase us like dogs”: Exploring the vulnerabilities of "ladyboys" in the Cambodian sex trade. Dignity: A Journal on Sexual Exploitation and Violence, 3(2). https://doi.org/10.23860/dignity.2018.03.02.01

Davis, J. D., \& Miles, G. M. (2020). "Strive harder and don't lose hope": Sexual exploitation of male youth in the sex trade in Manila. International Journal of Sociology and Social Policy. https://doi.org/10.1108/IJSSP-05-2020-0189

Davis, J. D., Glotfelty, E., \& Miles, G. M. (2017). "No other choice": A baseline study on the vulnerabilities of males in the sex trade in Chiang Mai, Thailand. Dignity: A Journal on Sexual Exploitation and Violence, 2(4). https://doi.org/10.23860.2017.02.04.10

Davis, J. D., Miles, G. M., Blackburn, S. \& Mosebach-Kornelsen, E. (2021). “There is always violence": An exploratory study of Phnom Penh, Cambodia, street-involved children. Dignity: A Journal on Sexual Exploitation and Violence, 6(1). https://doi.org/10.23860.2021.06.01.06

Davis, J. D., Miles, G. M. \& Quinley, J. H. (2019). "Same same, but different”: A baseline study on the vulnerabilities of transgender sex workers in the sex industry in Bangkok, Thailand. International Journal of Sociology and Social Policy, 39(7/8), 550-573. https://doi.org/10.1108/IJSSP-01-2019-0022

Davy, D. (2014). Understanding the complexities of responding to child sex trafficking in Thailand and Cambodia. The International Journal of Sociology and Social Policy, 34(11/12), 793-816. https://doi.org/10.1108/IJSSP-10-2013-0103

Davy, D. (2017). Justice for victims of human trafficking in Australia? Issues associated with Australia's criminal justice response to trafficking in persons. Contemporary Justice Review: Issues in Criminal, Social, and Restorative Justice, 20(1), 115-131. https://doi.org/10.1080/10282580.2016.1262773

Dell, N. A., Maynard, B. R., Born, K. R., Wagner, E., Atkins, B., \& House, W. (2019). Helping survivors of human trafficking: A systematic review of exit and postexit interventions. Trauma, Violence \& Abuse, 20(2), 183-196. https://doi.org/10.1177/1524838017692553

Downe, P. J. (2007). Strategic stories and reflexive interruptions: Narratives of a "safe home" amidst cross-border sex work. Qualitative Inquiry, 13(4), 554-572. https://doi.org/10.1177/1077800407300766

Glotfelty, E. J., \& Miles, G. M. (2018). (S)Expectations abroad: Male traveler interactions with Southeast Asian economies. Dignity: A Journal on Sexual Exploitation and Violence, 3(3). https://doi.org/10.23860.2018.03.03.04

Gray, G. G., Luna, L., \& Seegobin, W. (2012). Exploring resilience: Strengths of trafficking survivors in Cambodia. International Journal of Adolescent Medicine and Health, 24(4), 363-371. https://doi.org/10.1515/ijamh.2012.053

Hampton, M. D., \& Lieggi, M. (2020). Commercial sexual exploitation of youth in the United States: A qualitative systematic review. Trauma, Violence, \& Abuse, 21(1), 57-70. https://doi.org/10.1177/1524838017742168

Harper, E. A., Kruger, A. C., Varjas, K., \& Meyers, J. (2018). An organizational consultation framework for school-based prevention of commercial sexual exploitation of children. Journal of Educational and Psychological Consultation.

Hester, T. J., Kong, S., \& Miles, G. M. (2020). Barriers to sexually exploited Cambodian women integrating into churches: Perspectives of sexually exploited women and the Christian community. Dignity: A Journal on Sexual Exploitation and Violence, 5(1). https://doi.org/10.23860.2020.05.01.04

Hounmenou, C. \& O'Grady, C. (2019). A review and critique of the U.S. responses to the commercial sexual exploitation of children. Children and Youth Services Review, 98, 188-198. https://doi.org/10.1016/i.childyouth.2019.01.005 
Hughes, D. M. (2014). Trafficking in human beings in the European Union: Gender, sexual exploitation, and digital communication technologies. Sage Open, 4. https://doi.org/10.1177/2158244014553585

International Labor Organization (2017). Global estimates of modern slavery: Forced labour and forced marriage.

https://www.ilo.org/wcmsp5/groups/public/@dgreports/@dcomm/documents/p ublication/wcms 575479.pdf

Kaufman, M. R., \& Crawford, M. (2011). Sex trafficking in Nepal: A review of intervention and prevention programs. Violence Against Women, 17(5), 651-665. https://doi.org/10.1177/1077801211407431

Kiss, L., Pocock, N. S., Naisanguansri, V., Suos, S., Dickson, B., Thuy, D., ... \& Zimmerman, C. (2015a). Health of men, women, and children in post-trafficking services in Cambodia, Thailand, and Vietnam: An observational cross-sectional study. The Lancet Global Health, 3(3), e154-e161. https://doi.org/10.1016/S2214109X(15)70016-1

Kiss, L., Yun, K., Pocock, N., \& Zimmerman, C. (2015b). Exploitation, violence, and suicide risk among child and adolescent survivors of human trafficking in the Greater Mekong Subregion. JAMA Pediatrics, 169(9), 1-8. https://doi.org/10.1001/jamapediatrics.2015.2278

Knight, L., Xin, Y., \& Mengo, C. (2021). A scoping review of resilience in survivors of human trafficking. Trauma, Violence, \& Abuse.

Lasater, M. E., Grosso, A., Ketende, S., Lyons, C., Pitche, V. P., Tchalla, J., ... \& Baral, S. (2019). Characterising the relationship between migration and stigma affecting healthcare engagement among female sex workers in Lomé, Togo. Global Public Health: An International Journal for Research, Policy and Practice 14(10), 1428-1441. https://doi.org/10.1080/17441692.2019.1611896

Le, P. D. (2017). "Reconstructing a sense of self:" Trauma and coping among returned women survivors of human trafficking in Vietnam. Qualitative Health Research, 27(4), 509519. https://doi.org/10.1177/1049732316646157

Limoncelli, S. A. (2016). What in the world are anti-trafficking NGOs doing? Findings from a global study. Journal of Human Trafficking, 2(4), 316-328. https://doi.org/10.1080/23322705.2015.1135605

Macy, R. J., \& Johns, N. (2011). Aftercare services for international sex trafficking survivors: Informing U.S. service and program development in an emerging practice area. Trauma, Violence \& Abuse, 12(2), 87-98. https://doi.org/10.1177/1524838010390709

Mahalingam, R., \& Sidhu, J. S. (2020). Inside the crime of sex trafficking in Sabah, Malaysia. Journal of Human Trafficking. https://doi.org/10.1080/23322705.2019.1710069

McCarthy, L. A. (2018). Life after trafficking in Azerbaijan: Reintegration experiences of survivors. Anti-Trafficking Review, 10. https://doi.org/10.14197/atr.201218107

Miles, G., \& Alsiyao, D. (2019). "Disgusted with myself": Examining the risk factors and vulnerabilities of hostesses at karaoke TV venues in Phnom Penh, Cambodia. Dignity: A Journal on Sexual Exploitation and Violence 4(1). https://doi.org/10.23860/dignity.2019.04.01.09

Miles, G., Geyer, T., Ding, R., Blasé, O. \& Clark. K. (2020). “Don't look down on us”: Assessing the vulnerabilities of female massage parlor workers in Phnom Penh. International Journal of Sociology and Social Policy, 40(1/2), 1-19. https://doi.org/10.1108/IJSSP09-2018-0143

Molland, S. (2018). What happened to sex trafficking? The new moral panic of men, boys and fish in the Mekong Region. SOJOURN: Journal of Social Issues in Southeast Asia, 34(2), 397-424. https://doi.org/10.1355/sj34-Zf 
Muraya, D. N., \& Fry, D. (2016). Aftercare services for child victims of sex trafficking: A systematic review of policy and practice. Trauma, Violence, \& Abuse, 17(2), 204-220. https://doi.org/10.1177/1524838015584356

Nawyn, S. J., Birdal, N. B. K., \& Glogower, N. (2013). Estimating the extent of sex trafficking. International Journal of Sociology, 43(3), 55-71. https://doi.org/10.2753/I]S0020$\underline{7659430303}$

Nodzenski, M., Kiss, L., Pocock, N. S., Stoeckl, H., Zimmerman, C., \& Buller, A. M. (2020). Posttrafficking stressors: The influence of hopes, fears and expectations on the mental health of young trafficking survivors in the Greater Mekong Sub-region. Child Abuse \& Neglect, 100. https://doi.org/10.1016/i.chiabu.2019.104067

O'Brien, E. (2016). Human trafficking heroes and villains: Representing the problem in antitrafficking awareness campaigns. Social \& Legal Studies 2016, 25(2), 205-224. https://doi.org/10.1177/0964663915593410

Ong, T., Mellor, D., \& Chettri, S. (2019). Multiplicity of stigma: The experiences, fears and knowledge of young trafficked women in Nepal. Sexual and Reproductive Health Matters, 27(3), 32-38. https://doi.org/10.1080/26410397.2019.1679968

Oram, S., Stockl, H., Busza, J., Howard, L. M., \& Zimmerman, C. (2012). Prevalence and risk of violence and the physical, mental and sexual health problems associated with human trafficking: A systematic review. PLoS Medicine, 9(5), e1001223. https://doi.org/10.137/journal.pmed.1001224

Parks, A. C., Vincent, K., Russell, A., Nie, Z., \& Rusk, A. G. (2018). A study of public establishment-based and private network commercial sexual exploitation in Kolkata and Mumbai, India. Journal of Human Trafficking, 5(4), 281-311. https://doi.org/10.1080/23322705.2018.1488483

Price. K., Nelson, B., D., \& Macias-Konstantopoulos, W. L. (2019). Understanding health care access disparities among human trafficking survivors: Profiles of health care experiences, access, and engagement. Journal of Interpersonal Violence. https://doi.org/10.1177/0886260519889934

Puente-Martínez A., Ubillos-Landa, S., García-Zabala, M., \& Páez-Rovira, D. (2019). “Mouth wide shut": Strategies of female sex workers for coping with intimate partner violence. Journal of Interpersonal Violence, 34(16), 3414-3437 https://doi.org/10.1177/0886260516670180

Russell, A. (2018). Human trafficking: A research synthesis on human-trafficking literature in academic journals from 2000-2014. Journal of Human Trafficking, 4(2), 114-136. https://doi.org/10.1080/23322705.2017.1292377

Sethi, A. (2007). Domestic sex trafficking of Aboriginal girls in Canada: Issues and implications. First Peoples Child \& Family Review, 3(3), 57-71.

Studnicka, A. C. S. (2010). Corruption and human trafficking in Brazil: Findings from a multimodal approach. European Journal of Criminology 7(1), 29-43. https://doi.org/10.1177/1477370809347925

Thaller, J., \& Cimino, A. N. (2017). The girl is mine: Reframing intimate partner violence and sex work as intersectional spaces of gender-based violence. Violence Against Women, 23(2), 202-221. https://doi.org/10.1177/1077801216638766

Tsai, C., \& Dichter, M E. (2019). The trafficking of children in the Greater Mekong region: A review of recent literature. Child Abuse Review, 28(3), 198-208. https://doi.org/10.1002/car.2562

United Nations General Assembly (2000, November 15). Protocol to Prevent, Suppress and Punish Trafficking in Persons, Especially Women and Children; Supplementing the United Nations Convention against Transnational Organized Crime. https://www.ohchr.org/Documents/ProfessionalInterest/ProtocolonTrafficking.pdf 
Dignity: A Journal of Analysis of Exploitation and Violence, Vol. 6, Iss. 4 [2021], Art. 1

Williams, T. P., Alpert, E. J., Ahn, R., Cafferty, E., Konstantopoulos, W. M., Wolferstan, N., ... Burke, T. F. (2010). Sex trafficking and health care in Metro Manila: Identifying social determinants to inform an effective health system response. Health \& Human Rights, 12(2). https://www.hhrjournal.org

Zhang, S. X., Pacheco-McEvoy, R., \& Campo, R. (2012). Sex trafficking in Latin America: Dominant discourse, empirical paucity, and promising research. Global Crime, 13(1), 22-41. https://doi.org/10.1080/17440572.2011.632504. 